\title{
Inspiratory muscle endurance in obese and eutrophic individuals
}

\author{
Endurance muscular inspiratória em individuos obesos e eutróficos \\ La resistencia muscular inspiratoria en individuos obesos y eutróficos \\ Aline Dors Hoffmeister', Katieli Santos de Lima², Isabella Martins de Albuquerque ${ }^{3}$, Valderesa Binotto ${ }^{4}$, \\ Carine Cristina Callegaro 5
}

\begin{abstract}
I The objective of this study was to compare inspiratory muscle endurance and hemodynamic responses between obese and eutrophic individuals. In this cross-sectional study participated 20 obese individuals ( $31 \pm 6$ years old, 10 men, $37.5 \pm 4.7 \mathrm{~kg} / \mathrm{m}^{2}$ ) and 20 healthy subjects ( $29 \pm 8$ years old, 10 men, $23.2 \pm 1.5 \mathrm{~kg} / \mathrm{m}^{2}$ ). Inspiratory and expiratory muscle strength were measured by a manovacuometry through the determination of the maximum inspiratory pressure (MIP) and the maximum expiratory pressure (MEP), respectively. Inspiratory muscle endurance was determined by na incremental test with an initial load of $50 \%$ MIP and increments of 10\% MIP every 3 minutes until the individual was unable to continue the test. Obese $(470 \pm 326 \mathrm{sec})$ showed a reduction in inspiratory muscle endurance compared to eutrophic individuals (651 $\pm 215 \mathrm{sec}$ ). Inspiratory and expiratory muscle strength did not differ between groups. Inspiratory muscle endurance test induced a similar increase in systolic, diastolic and mean arterial pressure, as well as in heart rate in obese and eutrophic individuals. In conclusion, obese show reduction of inspiratory muscle resistance compared to eutrophic individuals, but the hemodynamic responses induced by inspiratory muscle resistance test did not differ between obese and eutrophic patients.
\end{abstract}

Keywords I Obesity; Inspiratory Reserve Volume; Hemodynamics; Arterial Pressure.
RESUMO I O objetivo deste estudo foi comparar a endurance muscular inspiratória e as respostas hemodinâmicas de indivíduos obesos e eutróficos. Tratase de um estudo transversal com amostra composta por

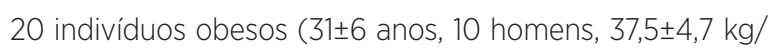

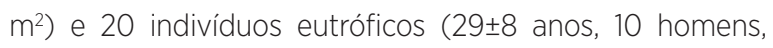
$23,2 \pm 1,5 \mathrm{~kg} / \mathrm{m}^{2}$ ). A força muscular inspiratória e expiratória foi mensurada por manovacuometria, através da determinação da pressão inspiratória máxima e da pressão expiratória máxima. A endurance muscular inspiratória foi determinada por meio de exercício inspiratório com carga progressiva, iniciado com carga de 50\% da pressão inspiratória máxima por 3 minutos, seguidos de incremento de 10\% a cada 3 minutos até que o indivíduo fosse incapaz de continuar o teste. Verificou-se que os indivíduos obesos (470 $\pm 326 \mathrm{seg}$ ) apresentaram endurance muscular inspiratória reduzida em comparação com os eutróficos

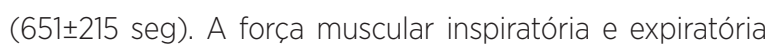
não diferiu entre os grupos. O teste de exercício progressivo induziu aumento da pressão arterial sistólica, diastólica e média e da frequência cardíaca, semelhante em indivíduos obesos e eutróficos. Foi possível concluir que embora a endurance muscular inspiratória de indivíduos obesos seja menor que a de eutróficos, as respostas hemodinâmicas induzidas pelo teste de endurance muscular inspiratória foram semelhantes nos dois grupos.

Descritores | Obesidade; Volume de Reserva Inspiratória; Hemodinâmica; Pressão Arterial.

Laboratório de Fisiologia da Universidade de Cruz Alta (Unicruz) - Cruz Alta (RS), Brazil.

'Programa de Pós-Graduação em Atenção Integral à Saúde pela Universidade de Cruz Alta (Unicruz) em rede com a Universidade Regional do Noroeste do Estado do Rio Grande Do Sul (Unijuí) - Cruz Alta (RS), Brazil.

¿2aboratório de Fisiologia da Universidade de Cruz Alta (Unicruz) - Cruz Alta (RS), Brazil.

${ }^{3}$ Departamento de Fisioterapia e Reabilitação e Programa de Pós-Graduação em Reabilitação Funcional da Universidade Federal de Santa Maria (UFSM) - Santa Maria (RS), Brazil.

${ }^{4}$ Universidade de Cruz Alta (Unicruz) - Cruz Alta (RS), Brazil.

${ }^{5}$ Departamento de Fisioterapia e Reabilitação, Laboratório de Fisiologia e Reabilitação, Universidade Federal de Santa Maria (UFSM) Santa Maria (RS), Brazil. 
RESUMEN I Este estudio pretende comparar la resistencia muscular inspiratoria con las respuestas hemodinámicas de individuos obesos y eutróficos. Se trata de un estudio transversal

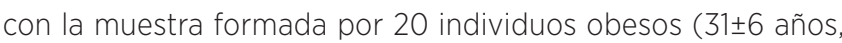
10 hombres, $\left.37,5 \pm 4,7 \mathrm{~kg} / \mathrm{m}^{2}\right)$ y 20 individuos eutróficos $(29 \pm 8$ años, 10 hombres, $23,2 \pm 1,5 \mathrm{~kg} / \mathrm{m}^{2}$ ). La fuerza muscular inspiratoria y espiratoria se midió por manovacuometría, por medio de la evaluación de la presión inspiratoria máxima y la presión espiratoria máxima. Se evaluó la resistencia muscular inspiratoria mediante el ejercicio inspiratorio con carga progresiva, que se inició con un 50 \% de carga de la presión inspiratoria máxima durante 3 minutos, siendo aumentada en un 10\% cada 3 minutos hasta que el individuo no pudiese continuar la prueba. Se encontró que los individuos obesos (470 $\pm 326 \mathrm{seg}$ ) tuvieron menor resistencia muscular inspiratoria comparados a los eutróficos (651 $\pm 215 \mathrm{seg}$ ). La fuerza muscular inspiratoria y espiratoria no difirió entre los grupos. La prueba de esfuerzo progresiva provocó el aumento de la presión arterial sistólica, diastólica y media, así como de la frecuencia cardíaca, tanto en los individuos obesos como en los eutróficos. Se concluyó que, aunque había sido menor la resistencia muscular inspiratoria en los individuos obesos comparados a los eutróficos, las respuestas hemodinámicas de la prueba de resistencia muscular inspiratoria fueron similares en ambos grupos.

Palabras clave I Obesidad; Volumen de Reserva Inspiratoria; Hemodinámica; Presión Arterial.

\section{INTRODUCTION}

Obesity may be related to reduced inspiratory muscle strength, leading to increased inspiratory effort, oxygen consumption, and energy expenditure ${ }^{1}$, which may contribute to high rates of diaphragmatic fatigue ${ }^{2}$. However, studies on respiratory muscle strength (RMS) of morbidly obese individuals have presented conflicting results $^{3}$. A research indicated that excess body weight does not change the respiratory muscle mechanics ${ }^{4}$, while another described that no association exists between RMS and body mass index (BMI) ${ }^{5}$. In addition, the inspiratory and expiratory muscle strength of obese individuals was within the bounds of normality when compared to eutrophic individuals 5 . On the other hand, two studies indicate an increase of RMS in morbidly obese individuals ${ }^{6,7}$.

In addition to the lack of consensus about the influence of obesity on RMS, apparently, inspiratory muscle endurance has not yet been investigated in obese individuals. There is only one study, recently published, which showed a significant association between body weight and inspiratory muscle endurance, assessed by inspiratory resistance exercises in eutrophic children and adolescents ${ }^{8}$.

In healthy individuals, the inspiratory resistance exercise increases blood pressure and heart rate ${ }^{9-11}$. These hemodynamic responses to the inspiratory resistance exercise may vary according to clinical conditions, such as chronic heart failure $(\mathrm{CHF})^{12,13}$ and diabetes mellitus ${ }^{14}$.

The effects of obesity on inspiratory muscle endurance and hemodynamic responses to the inspiratory resistance exercise have not yet been studied in obese individuals. From the hypothesis that inspiratory muscle endurance and hemodynamic responses are altered in obese individuals, the objective of this research was to compare the reaction of obese and eutrophic individuals to inspiratory resistance exercises.

\section{METHODOLOGY}

This is a cross-sectional study, with a convenience sample composed of obese $(n=20)$ and eutrophic $(n=20)$ individuals recruited by disclosure of the inclusion and exclusion criteria in social networks, family health strategies, and clinics specializing in the treatment of obesity. All volunteers were sedentary, non-smokers, and free of cardiovascular, pulmonary, neuromuscular, and infectious diseases. The obese individuals included had a BMI $>30 \mathrm{~kg} / \mathrm{m}^{2}$, while eutrophic individuals presented $\mathrm{BMI} \geq 18.5$ and $<25 \mathrm{~kg} / \mathrm{m}^{2}$, aged between 18 and 46 years. Eutrophic individuals were matched for sex and age in relation to the obese individuals. We excluded individuals with acute health problems or complaints arising in the last month (viral or bacterial infections, accidents, allergic reactions), nervous system diseases or conditions that affected the understanding and participation in the study, pregnancy, diabetes mellitus type I, symptomatic coronary artery disease, left ventricular dysfunction, bronchial asthma, chronic obstructive pulmonary disease, chronic neuropathies, and use of drugs such as corticosteroids or bronchodilators. 


\section{Materials and procedures}

On different days, the individuals were submitted to blood collection for laboratory tests, assessment of inspiratory and expiratory muscle strength, and inspiratory muscle endurance test.

\section{Laboratory tests}

After 12 hours of fasting, approximately $8 \mathrm{ml}$ of blood were collected from the individuals for laboratory analysis of blood glucose, triglycerides, and total cholesterol, HDL-C, LDL-C. The samples were processed on the same day of collection, with the serum being used to the analyses by the enzymatic method, by the device Biosystems Automatic Analyzer A-2515.

\section{Respiratory muscle strength assessment}

Inspiratory and expiratory muscle strength were determined by maximum inspiratory pressure (MIP) and maximum expiratory pressure (MEP), measured with an analogic manovacuometer (Famabras, Brazil), calibrated in $\mathrm{cmH}_{2} \mathrm{O}$ with an operating limit of $+/-300 \mathrm{cmH}_{2} \mathrm{O}$. Respiratory maneuvers were repeated until six measures with variation of less than $10 \%$ were obtained. The highest value obtained was used as MIP and as $\mathrm{MEP}^{16}$. The predicted values of MIP and MEP for the sex and age were calculated using the equation by Neder et al. ${ }^{17}$.

\section{Anthropometric assessments}

BMI was calculated by weight $(\mathrm{kg})$ divided by the squared height $\left(\mathrm{m}^{2}\right)$, as recommended by the World Health Organization $(\mathrm{WHO})^{18}$. The weight was measured with a scale (Plenna Slim Digital, Brazil) and the height with a stadiometer (Compacto E210 - Wiso ${ }^{\circledR}$, Brazil).

The waist and hip circumferences were measured with a measure tape with a scale from 0 to $250 \mathrm{~cm}$. The waist-hip ratio was calculated by dividing the waist circumference by the hip circumference. The measurements were taken while the individuals were in the orthostatic posture ${ }^{19}$.

\section{Inspiratory muscle endurance assessment}

First, MIP was determined. After 15 minutes of rest, individuals sat for measurement of blood pressure, heart rate, and blood oxygen saturation. The inspiratory muscle endurance test was conducted with the participants using a nasal clip, while they breathed continuously through a nozzle connected to a linear inspiratory resistance (POWERbreathe, Southam, United Kingdom) of 50\% of the MIP with a $10 \%$ increment of the MIP every three minutes, until the individual showed to be unable to continue the test. Individuals should maintain a respiratory rate of 15 breaths per minute, following a specific audio signal for inspiration and expiration from a metronome. We used as inspiratory muscle endurance measure the highest inspiratory pressure value sustained by at least 60 seconds (Pthmax), expressed as a percentage of MIP (Pthmax/MIP) ${ }^{20,21}$, as well as test duration expressed in seconds.

Hemodynamic variables were measured at rest and at the end of the inspiratory muscle endurance test. Blood pressure was measured in the non-dominant arm with a sphygmomanometer (Unilet ${ }^{\circledR}$, Brazil). The cuff was positioned from 2 to $3 \mathrm{~cm}$ above the cubital fossa and without excessive compression of the stethoscope to the brachial artery. Systolic blood pressure was estimated by auscultation of the first sound (Korotkoff phase I) and diastolic blood pressure by the disappearance of sounds (Korotkoff phase V) ${ }^{22}$. Heart rate and blood oxygen saturation was measured by a pulse oximetry (Fingertip Pulse Oximeter, China).

The data were analyzed, expressed as mean and standard deviation and distributed as determined by the Kolmogorov-Smirnov test. To analyze the results, the software SPSS 22.0 was used. The inspiratory muscle strength and endurance were compared between obese and eutrophic individuals by Student's t-test for independent samples. The analysis of variance for repeated measurements (ANOVA) was used to assess the effects of the inspiratory muscle endurance test on the hemodynamic variables in obese and eutrophic individuals. The association among variables was analyzed by Pearson correlation. A p-value $<0.05$ was considered significant.

\section{RESULTS}

Regarding the clinical assessment, the groups did not differ as to age and sex. As for the anthropometric assessment, although the obese individuals, as expected, presented greater body weight, higher BMI, and higher waist and hip circumference measures than the eutrophic individuals, waist-hip ratio did not differ between the groups. The obese individuals were stratified in degrees 
of obesity: 6 of them were grade I, 9 grade II, and 5 were grade III obese. The laboratory assessment showed higher glycemia, triglycerides, and total cholesterol levels in obese individuals, compared to the eutrophic individuals (Table 1).

Table 1. Clinical characteristics of obese and eutrophic individuals

\begin{tabular}{|c|c|c|c|}
\hline & $\begin{array}{l}\text { Obese } \\
(n=20)\end{array}$ & $\begin{array}{l}\text { Eutrophic } \\
(n=20)\end{array}$ & p \\
\hline Age (years) & $31.40 \pm 6$ & $29.45 \pm 8$ & 0.389 \\
\hline Sex (male/female) & 10 Male & 10 Male & \\
\hline Weight (kg) & $107.3 \pm 18.7$ & $66.0 \pm 8.8$ & $0.001^{*}$ \\
\hline Height (m) & $1.68 \pm 0.8$ & $1.68 \pm 0.1$ & 0.879 \\
\hline BMI $\left(\mathrm{kg} / \mathrm{m}^{2}\right)$ & $37.5 \pm 4.7$ & $23.2 \pm 1.5$ & $0.001^{*}$ \\
\hline Waist circumference $(\mathrm{cm})$ & $112.8 \pm 10$ & $81.7 \pm 8.7$ & $0.001^{*}$ \\
\hline Hip circumference (cm) & $121.8 \pm 10.3$ & $89.4 \pm 8.1$ & $0.001^{*}$ \\
\hline Waist-hip ratio & $0.92 \pm 0.09$ & $0.91 \pm 0.07$ & 0.610 \\
\hline Fasting blood glucose ( $\mathrm{mg} / \mathrm{dL})$ & $92.6 \pm 12.6$ & $75.65 \pm 7.4$ & $0.001^{*}$ \\
\hline Triglycerides (mg/dL) & $128 \pm 53$ & $91 \pm 32$ & $0.013^{*}$ \\
\hline Cholesterol (mg/dL) & $166 \pm 32$ & $147 \pm 23$ & $0.046^{*}$ \\
\hline
\end{tabular}

BMI: body mass index. ${ }^{p} \mathrm{p}=0.05$

Table 2 shows that inspiratory muscle strength, represented by the MIP, and expiratory muscle strength, represented by the MEP, presented no significant differences between obese and eutrophic individuals for both absolute and the predicted values for sex and age, according to the equation proposed by Neder et al. ${ }^{17}$. The duration of the inspiratory muscle endurance test for eutrophic individuals $(651 \pm 215 \mathrm{seg})$ was higher than among obese individuals $(470 \pm 326 \mathrm{seg}, \mathrm{p}=0.04)$. However, the MIP reached at the end of the test did not differ significantly between the groups (obese $=77 \pm 24 \mathrm{cmH}_{2} \mathrm{O}$; eutrophic $\left.=84 \pm 26 \mathrm{cmH}_{2} \mathrm{O}, \mathrm{p}=0.88\right)$. At rest, the obese individuals showed systolic and diastolic blood pressure and heart rate higher than that of eutrophic individuals. However, the increase in systolic and diastolic blood pressure and heart rate was similar in both groups at the end of the inspiratory muscle endurance test. As for peripheral oxygen saturation, it did not undergo changes due to the test (Table 3).

Table 2. Respiratory muscle force values in the sample

\begin{tabular}{|c|c|c|}
\hline & $\begin{array}{l}\text { Obese } \\
(n=20)\end{array}$ & $\begin{array}{c}\text { Eutrophic } \\
(n=20)\end{array}$ \\
\hline $\mathrm{MIP}\left(\mathrm{cmH}_{2} \mathrm{O}\right)$ & $120.1 \pm 45.1$ & $118.0 \pm 31.3$ \\
\hline$\%$ predicted MIP & $105.5 \pm 26.1$ & $103.7 \pm 25.7$ \\
\hline $\operatorname{MEP}\left(\mathrm{cmH}_{2} \mathrm{O}\right)$ & $113.5 \pm 41.4$ & $121.0 \pm 26.0$ \\
\hline$\%$ predicted MEP & $96.3 \pm 24.2$ & $102.2 \pm 18.3$ \\
\hline
\end{tabular}

MIP: maximum inspiratory pressure ( $p=0.814) ; \%$ predicted MIP: percentage of the predicted maximum inspiratory pressure for sex and age ( $p=0.670)$; MEP: maximum expiratory pressure $(p=0.496) ; \%$ predicted MEP: percentage of the predicted maximum expiratory pressure for sex and age $(p=0.395)$
Table 3. Hemodynamic responses during the inspiratory muscle endurance test

\begin{tabular}{lcccccc} 
& \multicolumn{2}{c}{$\begin{array}{c}\text { Obese } \\
(\mathrm{n}=20)\end{array}$} & \multicolumn{2}{c}{$\begin{array}{c}\text { Eutrophic } \\
(\mathrm{n}=20)\end{array}$} & $\mathrm{p}$ & $\mathrm{p}$ \\
\cline { 2 - 7 } & Pre & Post & Pre & Post & $\begin{array}{c}\text { Obese vs. } \\
\text { Eutrophic }\end{array}$ & $\begin{array}{c}\text { Pre vs. } \\
\text { Post }\end{array}$ \\
$\mathrm{SBP}(\mathrm{mmHg})$ & $133 \pm 12^{+}$ & $143 \pm 2^{*}$ & $117 \pm 12$ & $127 \pm 15^{*}$ & 0.001 & 0.001 \\
$\mathrm{DBP}(\mathrm{mmHg})$ & $84 \pm 12^{+}$ & $93 \pm 14^{*}$ & $77 \pm 8$ & $81 \pm 8^{*}$ & 0.004 & 0.001 \\
$\mathrm{HR}(\mathrm{bpm})$ & $84 \pm 15^{+}$ & $92 \pm 22^{*}$ & $79 \pm 9$ & $87 \pm 10^{*}$ & 0.001 & 0.003 \\
$\mathrm{SpO}_{2}(\%)$ & $97 \pm 1.5^{+}$ & $97 \pm 3.6$ & $98 \pm 1.0$ & $98 \pm 1.5$ & 0.021 & 0.907
\end{tabular}

SBP: systolic blood pressure; DBP: diastolic blood pressure; $\mathrm{HR}$ : heart rate; $\mathrm{SpO}_{2}$ : peripheral oxygen saturation; " $p<0.05$ vs. rest; ${ }^{\dagger}<<0.05$ vs. non-obese

The duration of the inspiratory muscle endurance test was inversely associated with BMI ( $r=-0.37 ; \mathrm{p}=0.020)$. However, there was no significant association between the percentage of MIP, reached at the inspiratory muscle endurance test, and BMI $(r=-0.13 ; \mathrm{p}=0.41)$. There was also no correlation between the MIP reached at progressive inspiratory muscle endurance test and BMI ( $r=-0.013 ; p=0.93)$.

\section{DISCUSSION}

This study showed that the inspiratory muscle endurance of obese individuals is less than that of eutrophic individuals. However, hemodynamic responses, induced by the inspiratory resistance exercise, were similar in both groups.

From the assumption that the inspiratory muscle endurance is important for the analysis of respiratory disorders and that its assessment is simple and of easy applicability, studying it in the obese population becomes relevant. It should be noted that so far we did not found in the literature any study that investigated if obesity changes the inspiratory muscle endurance, only one research with healthy children and adolescents, non-obese, which demonstrated the correlation between progressive inspiratory muscle endurance test performance and weight and height ${ }^{8}$.

Our study showed that inspiratory muscle endurance is inversely associated with BMI. Obesity did not alter the hemodynamic responses to inspiratory muscle resistance exercises, possibly due to the preservation of inspiratory muscle strength in obese individuals. Corroborating this finding, previous studies reported that obesity does not alter the strength of inspiratory muscles ${ }^{23}$, which can even be found within the range of normalcy ${ }^{5}$. In our research, 
workload during the inspiratory resistance exercise test was similar for obese and eutrophic individuals, however the duration of the exercise was greater in eutrophic individuals, suggesting greater work ability than obese individuals. Possibly, this reduced inspiratory muscle endurance is related to the type of muscle fiber and metabolic profile during muscular contraction ${ }^{24}$.

In fact, the inspiratory endurance test held until fatigue can accumulate metabolites that stimulate the metaboreceptors to activate the sympathetic nervous system and peripheral vasoconstriction, raising arterial pressure ${ }^{25,26,11}$. Despite the hemodynamic responses during the inspiratory resistance exercise being similar among obese and eutrophic individuals, the physiological mechanism may differ between the groups. In a preliminary study, the manual grasping exercise elevated the mean arterial pressure in obese and eutrophic children in a similar way, but the increase in blood pressure in eutrophic children was mediated by the increase of peripheral vascular resistance, while in obese children, it was induced by the increase in the systolic volume ${ }^{27}$.

Corroborating previous studies ${ }^{28,29}$, the obese individuals in this study showed cardiovascular adaptations such as high systolic, diastolic, and mean blood pressure, as well as heart rate at rest. These changes can be explained by the effects of visceral adipose tissue in the increasing of the activity of the sympathetic nervous system ${ }^{30}$ and of angiotensin II, which, associated with endothelial dysfunction ${ }^{31}$, affects the elevation of the systemic vascular resistance and, therefore, blood pressure ${ }^{29}$.

The clinical relevance of this study is characterized by the applicability of the assessment of the inspiratory muscle endurance in the obese population, until then poorly studied. In addition to this aspect, the finding of decreased inspiratory muscle endurance in obese individuals can provide information about the limitations imposed by obesity on exercise capacity, suggesting that strength and inspiratory muscle endurance can be used to determine goals for physical training programs ${ }^{32}$.

\section{CONCLUSION}

This study showed that, compared to eutrophic individuals, obese individuals present reduced inspiratory muscle endurance, although the hemodynamic responses induced by inspiratory muscle endurance tests is similar in both groups.

\section{REFERENCES}

1. Mafort TT, Rufino R, Costa CH, Lopes AJ. Obesity: systemic and pulmonary complications, biochemical abnormalities, and impairment of lung function. Multidiscip Respir Med. 2016;11(1):28. doi: 10.1186/s40248-016-0066-z

2. Rigatto AM, Alves SCC, Gonçalves CB, Firmo JF, Provin LM. Performance ventilatória na obesidade. Saúde Rev. 2005;7(17):57-62.

3. Pazzianotto-Forti EM, Peixoto-Souza FS, Piconi-Mendes C, Rasera-Junior I, Barbalho-Moulim M. Behavior of respiratory muscle strength in morbidly obese women by using different predictive equations. Braz J Phys Ther. 2012;16(6):479-86. doi: 10.1590/S1413-35552012000600006

4. Magnani KL, Cataneo AJM. Respiratory muscle strength in obese individuals and influence of upper-body fat distribution. São Paulo Med J. 2007;125(4):215-9. doi: 10.1590/S1516-31802007000400004

5. Domingos-Benício NC, Gastaldi AC, Perecin JC, Avena KM, Guimarães RC, Sologuren MJJ, et al. Influência do peso corporal sobre as pressões respiratórias máximas nas posições sentada, deitada e em pé. Rev Bras Fisioter. 2003;7(3):217-22.

6. Simoneau JA, Veerkamp JH, Turcotte LP, Kelley DE. Markers of capacity to utilize fatty acids in human skeletal muscle: relation to insulin resistance and obesity and effects of weight loss. FASEB J. 1999;13(14):2051-60.

7. Hulens M, Vansant G, Lysens R, Claessens AL, Muls E, Brumagne S. Study of differences in peripheral muscle strength of lean versus obese women: an allometric approach. Int J Obes. 2001;25(5):676. doi: 10.1038/sj.ijo.0801560

8. Woszezenki CT, Heinzmann-Filho JP, Vendrusculo FM, Piva TC, Levices I, Donadio MVF. Reference values for inspiratory muscle endurance in healthy children and adolescents. PloS One. 2017;12(1):e0170696. doi: 10.1371/journal.pone.0170696

9. St Croix CM, Morgan BJ, Wetter TJ, Dempsey JA. Fatiguing inspiratory muscle work causes reflex sympathetic activation in humans. Physiol J. 2000;529(2):493-504. doi: 10.1111/j.1469-7793.2000.00493.x

10. Sheel AW, Derchak PA, Morgan BJ, Pegelow DF, Jacques AJ, Dempsey JA. Fatiguing inspiratory muscle work causes reflex reduction in resting leg blood flow in humans. Physiol J. 2001;537(1):277-89. doi: 10.1111/j.1469-7793.2001.0277k.x

11. Callegaro CC, Ribeiro JP, Tan CO, Taylor JA. Attenuated inspiratory muscle metaboreflex in endurance-trained individuals. Respir Physiol Neurobiol. 2011;177(1):24-9. doi: 10.1016/j.resp.2011.03.001

12. Ribeiro JP, Chiappa GR, Callegaro CC. Contribuição da musculatura inspiratória na limitação ao exercício na insuficiência cardíaca: mecanismos fisiopatológicos. Rev Bras Fisioter. 2012;16(4):261-7.

13. Chiappa GR, Roseguini BT, Vieira PJ, Alves CN, Tavares A, Winkelmann ER, et al. Inspiratory muscle training improves blood flow to resting and exercising limbs in patients with chronic heart failure. J Am Coll Cardiol. 2008;51(17):1663-71. doi: 10.1016/j.jacc.2007.12.045

14. Corrêa AP, Ribeiro JP, Balzan FM, Mundstock L, Ferlin EL, Moraes RS. Inspiratory muscle training in type 2 diabetes with inspiratory muscle weakness. Med Sci Sports Exerc. 2011;43(7):1135-41. doi: 10.1249/MSS.0b013e31820a7c12 
15. Associação Brasileira de Medicina Diagnóstica; Sociedade Brasileira de Análises Clínicas; Sociedade Brasileira de Cardiologia; Sociedade Brasileira de Diabetes; Sociedade Brasileira de Patologia Clínica. Consenso Brasileiro para a Normatização da Determinação Laboratorial do Perfil Lipídico [Internet]. Rio de Janeiro: Sociedade Brasileira de Análises Clínicas; 2016 [cited 2018 Oct 9]. 5 p. Available from: www.sbac.org.br/wp-content/uploads/2017/09/ConsensoOficial_ PerfilLipidico_2016_v13.pdf

16. Callegaro CC, Martinez D, Ribeiro PA, Brod M, Ribeiro JP. Augmented peripheral chemoreflex in patients with heart failure and inspiratory muscle weakness. Respir Physiol Neurobiol. 2010;171(1):31-5. doi: 10.1152/ajpregu.00419.2014

17. Neder JA, Andreoni S, Lerario MC, Nery LE. Reference values for lung function tests: II. Maximal respiratory pressures and voluntary ventilation. Braz J Med Biol Re. 1999;32(6):719-27.

18. Associação Brasileira para o Estudo da Obesidade e da Síndrome Metabólica. Diretrizes Brasileiras de Obesidade 2009/2010 [Internet]. 3rd ed. Itapevi: AC Farmacêutica; 2009 [cited 2018 Oct 9]. 83 p. Available from: http://www.abeso.org. br/pdf/diretrizes_brasileiras_obesidade_2009_2010_1.pdf

19. Lima LF, Ghetti FF, Lacerda KC, Silva AA, Luquetti SCPD. Relação entre medidas antropométricas, escolaridade, renda e índice de qualidade da dieta de mulheres climatéricas. HU Revista. 2017;42(4):297-305.

20. Martyn JB, Moreno RH, Pare PD, Pardy RL. Measurement of inspiratory muscle performance with incremental threshold loading. Am Rev Respir Dis. 1987;135(4),919-23.

21. Dall'Ago P, Chiappa GR, Guths H, Stein R, Ribeiro JP. Inspiratory muscle training in patients with heart failure and inspiratory muscle weakness: a randomized trial. J Am Coll Cardiol. 2006;47(4):757-63. doi: 10.1016/j.jacc.2005.09.052

22. Malachias MVB, Souza WKSB, Plavnik FL, Rodrigues CIS, Brandão AA, Neves MFT, et al. 7ª Diretriz Brasileira de Hiptertensão Arterial. Arq Bras Cardiol. 2016;107(3Supl.3):1-81. doi: 10.5935/abc.20160152

23. Woszezenki CT, Heinzmann-Filho JP, Vendrusculo FM, Piva TC, Levices I, Donadio MVF. Reference values for inspiratory muscle endurance in healthy children and adolescents. PLoS One. 2017;12(1):e0170696. doi: 10.1371/journal.pone.0170696

24. Magnani KL, Cataneo AJM. Respiratory muscle strength in obese individuals and influence of upper-body fat distribution. Sao Paulo Med J. 2007;125(4):215-19. doi: 10.1590/S1516-31802007000400004

25. Tallis J, Hill C, James RS, Cox VM, Seebacher F. The effect of obesity on the contractile performance of isolated mouse soleus, EDL, and diaphragm muscles. J Appl Physiol. 2017;122(1):170-81. doi: 10.1152/japplphysiol.00836.2016

26. Sheel AW, Derchak PA, Pegelow DF, Dempsey JA. Threshold effects of respiratory muscle work on limb vascular resistance. Am J Physiol Heart Circ Physiol. 2002;282(5):H1732-H18. doi: 10.1152/ajpheart.00798.2001.

27. Dipla K, Zafeiridis A, Koidou I, Geladas N, Vrabas IS. Altered hemodynamic regulation and reflex control during exercise and recovery in obese boys. Am J Physiol Heart Circ Physiol. 2010;299(6):H2090-H6. doi: 10.1152/ajpheart.00087.2010

28. Trombetta IC, Batalha LT, Rondon MUP, Laterza MC, Kuniyoshi FH, Gowdak MM, et al. Weight loss improves neurovascular and muscle metaboreflex control in obesity. Am J Physiol Heart Circ Physiol. 2003;285(3):H974-H82. doi: 10.1152/ajpheart.01090.2002

29. Pierce GL, Beske SD, Lawson BR, Southall KL, Benay FJ, Donato AJ, et al. Weight loss alone improves conduit and resistance artery endothelial function in young and older overweight/obese adults. Hypertension. 2008;52(1):72-9. doi: 10.1161/HYPERTENSIONAHA.108.111427

30. Negrão CE, Rondon MUPB. Exercício físico, hipertensão e controle barorreflexo da pressão arterial. Rev Bras Hipertens. 2011;8(1):89-95.

31. Cerrone LA, Poli VFS, Sanches RB, Andrade-Silva SG, Fidalgo JPN, Nascimento MA, et al. Terapia interdisciplinar e a diminuição da sobrecarga cardiovascular em obesos. Int J Cardiovasc Sci. 2017;30(2):128-35. doi: 10.5935/2359-4802.20170039

32. Donato L, Maldaner L, Horn RC, Chaves L, Kohl LM, Albuquerque IM, et al. Treinamento muscular inspiratório em indivíduos obesos: um estudo piloto. Saúde (Santa Maria). 2017;43(2):83-90. doi: $10.5902 / 2236583423737$ 